\author{
S. Pohasii ${ }^{1}$, S. Milevskyi ${ }^{1}$, O. Zhuchenko ${ }^{2}$, B. Tomashevsky ${ }^{3}$, I. Rahimova ${ }^{4}$, S. Serhiiev $^{5}$ \\ ${ }^{1}$ Simon Kuznets Kharkiv National University of Economics, Kharkiv \\ ${ }^{2}$ Ukrainian State University of Railway Transport, Kharkiv \\ ${ }^{3}$ Ternopil Ivan Puluj National Technical University, ${ }^{3}$ Ternopil \\ ${ }^{4}$ Azerbaijan Technical University, Baku \\ ${ }^{5}$ Scientific-Research Center of Missile Troops and Artillery, Sumy
}

\title{
DEVELOPMENT OF NIEDERRITER CRYPTO-CODE DESIGN MODELS ON LDPC-CODES
}

\begin{abstract}
The development of mobile technologies and computing resources has expanded the range of digital services and practically outstripped the development of computer technologies. This approach ensures the use of mobile and wireless networks in almost all areas of smart technologies, provides a further synthesis of cyberspace and the mobile Internet. However, the absence of security service protocols: confidentiality and integrity, initially when they are formed in the structure of LTE technologies, provides cyber attackers with the opportunity to use mobile Internet channels to implement targeted (APT) attacks. The development and emergence of a full-scale quantum computer with Shor and Grover algorithms can lead to a sharp decrease in the level of security of cryptosystems based on symmetric and asymmetric cryptography (including cryptography on elliptic curves). In addition, modern cyber threats have signs of synergy and hybridity, and their integration with social engineering methods practically does not allow providing the required level of preventive measures (protection). The article proposes post-quantum cryptosystems based on the Niederreiter crypto-code construction on low-density parity-check codes (LDPC-codes). This approach makes it easy to integrate into wireless networks based on IEEE 802.16 and IEEE 802.15.4 standards, as well as LTE mobile technologies. At the same time, the required level of resistance to modern threats ensured.
\end{abstract}

Keywords: modified Niederreiter crypto-code construction, post-quantum period, codes with low density of parity checks.

\section{Introduction}

Problem statement. The development of mobile technologies and wireless networks has determined the vectors for creating fundamentally new approaches to expanding the range of services based on wireless and mobile networks based on IEEE 802.16 and IEEE 802.15.4 technologies. Further development of mobile LTE technologies makes it possible to connect technologies of the Internet of things, cyber-physical systems with LTE technologies, and form Mesh and/or sensor networks, develop smart technologies and form socio-cyber-physical systems. However, in the context of the integration of modern cyber threats with social engineering methods, the possibility of manifestation of synergy and hybridity of APT attacks (targeted attacks), it becomes necessary to consider security in the spectrum of three components: cyber security (CS), information security (IS), security of information (SI) [1]. This approach ensures the formation of timely preventive measures to ensure the safety of business processes, and the formation of a safety loop. For the formation of security services, as a rule, symmetric and asymmetric cryptosystems are used (the strength of the first is based on the strength of key sequences and S-boxes, and the second on complexity-theoretic problems (NP-complete problems). However, the rapid development of quantum computing can significantly reduce the security of these cryptosystems based on the quantum algorithms of Shor and Grover [2-6], which requires the formation of new approaches to the creation and/or modification of known cryptosystems - the formation of post-quantum cryptography. Unfortunately, in addition to this, the analysis of the effectiveness of security mechanisms in LTE technologies practically does not provide a minimum level of security [7-9], which significantly affects the further development of these technologies. Thus, the issues of ensuring the security of this development of socio-cyber-physical systems, smart systems based on post-quantum algorithms is an urgent scientific and technical problem.

Analysis of recent research and publications [1-6; 11-17; 19-20] showed that in the conditions of the emergence of a full-scale quantum computer based on the quantum algorithms of Shor and Grover, the provision of the required level of security not only in critical infrastructure objects, but also in cyberspace in general, is questioned. Therefore, since 2016, US NIST specialists have been holding a competition for post-quantum cryptography algorithms, where at the third stage in the group of asymmetric cryptosystems the McEliece crypto-code construction (CCC) on classical codes is in 
the lead [21]. An alternative solution is the Niederreiter crypto-code construction [10-13], which is based on the same principles as the McEliece crypto-code construction [13]: masking matrices are used as the private key $[3-6 ; 10-13 ; 22]: X^{i}$ - disguise nondegenerate randomly equiprobably formed by a source of keys $k \times k$ matrix with elements from $G F(q) ; P^{i}$ - permutation randomly equiprobably formed by a source of keys $n \times n$ matrix with elements from $G F(q) ; D^{i}$ - diagonal formed by a source of keys $n \times n$ matrix with elements from $G F(q)$; and the public key in the Niederreiter $\mathrm{CCC}$ is the product of the masking matrices by the parity check matrix of the linear block code: $H_{X}^{u}=X^{u} \cdot H \cdot P^{u} \cdot D^{u}, u \in\{1,2, \ldots, s\}$. The main difference and advantage of the Niederreiter CCC in comparison to the McEliece CCC is the provision of the maximum coding rate, which can significantly affect its use in socio-cyber-physical systems (SCPS). However, in [22], an algorithm for breaking the McEliece CCC based on fractional linear transformations and the triple transitivity property of the group of automorphisms of the generalized Reed-Solomon code is given. The essence of which is to find the elements of the generating matrix and remove the action of the masking matrices. The orthogonality of the generative and test matrices allows us to consider the effectiveness of the attack on the Niederreiter CCC as well. A promising direction for eliminating the revealed regularities in [22] proposes to use cascade or algebraic geometric codes (AGC) - codes built on the basis of the algebra of the theory of errorcorrecting coding and geometric parameters of a curve, in particular, elliptic curves. In [3-6; 10-13], models and practical algorithms for the implementation of CCC on algebraic geometric codes are considered. However, in the context of the development of socio-cyber-physical systems based on the 3GPP consortium [23] in the fifth generation 5G New Radio (NR) networks, LDPC codes with a low density of parity checks - will be used as an error-correcting code. LDPC is implemented in many modern data transmission standards, in the frequency of IEEE 802.11n (Wi-Fi), IEEE 802.16e (WiMAX), IEEE 802.15.4 (ZigBee), digital television (DVBS2 (T2), DMB-T), and communication systems with near and deep space (CCSDS). The main advantage of these codes is the ability to provide information processing on a modern element base at a rate of up to 1 Gbit / s with a signal-to-noise ratio of about $2 \mathrm{~dB}$ or less $[14 ; 19-20]$.

Thus, the use of the proposed solutions for the implementation of the CCC at the AGC will not provide the required compatibility with the already used codes, and their implementation will increase the energy consumption of this implementation, which is not desirable in the context of the use of wireless communication lines based on LTE technologies.

In [15], two approaches to the construction of McEliece's CCC on LDPC are considered, however, in terms of the relative coding rate, it is inferior to the Niederreiter $\mathrm{CCC}$, which allows us to consider this $\mathrm{CCC}$ as the main one for providing security services in the SCPS.

The purpose of the article is to form a mathematical model of the Niederreiter crypto-code construction on codes with a low density of parity checks.

\section{Statement of basic materials}

Development of a Niederreiter crypto-code construction on LDPC codes model

We use the model in [13] as a formal basis for the mathematical model of the Niederreiter CCC on LDPC codes, then:

- set of plaintext $M=\left\{M_{1}, M_{2}, \ldots M_{q^{k}}\right\}$, where $M_{i}=\left\{e_{0}, e_{h_{1}}, \ldots e_{h_{k}}, e_{e-1}\right\}, \quad \forall e_{e} \in G F(q), h_{e}-$ error vector characters equal to zero, $|h|=\frac{1}{2} e$, that is $e_{i}=0, \forall e_{i} \in h$;

- a set of closed texts $S=\left\{S_{0}, S_{1}, \ldots S_{q^{r}}\right\}$, where $S_{i}=\left\{S_{X_{0}}^{*}, S_{h_{1}}^{*}, \ldots S_{h_{j}}^{*}, S_{X_{r}}^{*}\right\}, \forall S_{X_{r}} \in G F(q) ;$

- set of direct mappings (based on the use of public key - LDPC code check matrix): $\varphi=\left\{\varphi_{1}, \varphi_{2}, \ldots, \varphi_{r}\right\}$, where $\varphi_{i}: M \rightarrow S_{r-h_{e}}, i=1,2, \ldots, e$ - set of inverse mappings (based on the use of private key - masking matrices).

$\varphi^{-1}=\left\{\varphi_{1}^{-1}, \varphi_{2}^{-1}, \ldots, \varphi_{r}^{-1}\right\}$, where $\varphi_{i}^{-1}: S_{r-h_{e}} \rightarrow M$, $i=1,2, \ldots, e$.

- set of keys that parameterize direct mappings (public key of the authorized user):

$$
K U_{i}=\left\{K U_{1}, K U_{2}, \ldots, K U_{r}\right\}=\left\{H_{1}, H_{2}, \ldots, H_{r}\right\},
$$

where $H_{X_{a_{i}}}^{L D P C_{i}}$ - testing $(N-K) \times N$ and allows to express $(N-K)$ test symbols $P_{1}, P_{2}, \ldots, P_{N-K}$ in the form of a linear combination of information symbols $d_{k}, k=1,2, \ldots, K$, that is, determines the test equations:

$$
\begin{aligned}
& P_{1}=c_{11} d_{1} \oplus c_{21} d_{2} \oplus \ldots \oplus c_{k 1} d_{K} ; \\
& P_{2}=c_{12} d_{1} \oplus c_{22} d_{2} \oplus \ldots \oplus c_{k 2} d_{K} ; \\
& \ldots \ldots \ldots \ldots . . \\
& P_{N-K}=c_{1 N-K} d_{1} \oplus c_{2 N-K} d_{2} \oplus \ldots \oplus c_{K N-K} d_{K},
\end{aligned}
$$

where $c_{i j}-$ submatrix elements $A, c_{i j}=0,1$, $d_{k}, k=1,2, \ldots, K-$ statistically independent symbols that take the values 0 and 1 , and which, in the general 
case, correspond to the information symbols of the block code [18];

- set of keys that parameterize inverse mappings (private key of the authorized user):

$K R=\left\{K R_{1}, K R_{2}, \ldots, K R_{r}\right\}=\left\{\begin{array}{l}\{X, P, D\}_{1}, \\ \{X, P, D\}_{2}, \ldots,\{X, P, D\}_{r}\end{array}\right\}$, $\{X, P, D\}_{i}=\left\{X^{i}, P^{i}, D^{i}\right\}$, where $X^{i}$ - masking degenerate accidentally equally likely formed by the source of the keys $k \times k$ matrix with elements of $G F(q) ; P^{i}-$ permutation randomly equally likely formed by the source of the keys $n \times n$ matrix with elements of $G F(q) ; D^{i}$ - diagonal matrix generated by the key source with elements of $G F(q)$ that is $\varphi_{i}^{-1}: S_{r-h_{e}}^{*} \stackrel{K R_{i}}{\longrightarrow} M, i=1,2, \ldots, s$. Due to the fact that the diagonal matrix is equal to a single matrix $\left(\left\|D^{i}\right\|=\|E\|\right)$, and its value can be neglected, which reduces the capacity and complexity of the calculation. The difficulty of performing the inverse mapping $\phi_{i}^{-1}$ without knowledge of the key $K_{i}^{*} \in K^{*}$ associated with solving a theoretically complex problem of decoding a random code (general position code).

The initial data in the description of the considered crypto-code construction are:

- equilibrium code over $G F(q)$, ie the set of sequences of length $n$;

- block $(N, K)$-code $C$ over $G F(q)$, that is, such a set of code words $C_{i} \in C$, that is fulfilled equality $C_{i} H^{T}=0$, where $H^{L D P C}$ - LDPC-code check matrix;

- masking matrix mappings defined by a set of matrices $\{X, P, D\}_{i}$, where $X$ - nondegenerate $k \times k$ matrix over $G F(q), P$ - permutable $n \times n$ matrix over $G F(q)$ with one non-zero element in each row and in each column of the matrix, $D$ - diagonal $n \times n$ matrix over $G F(q)$ with non-zero elements on the main diagonal.

On the basis of equilibrium coding $g$ is the transformation of plaintext into an error vector (closed text $C_{j} \in C$ ) according to the entered plaintext $M_{i} \in M$ and the specified key $H^{L D P C u}, u \in\{1,2, \ldots, s\}$. This is done by forming a syndrome sequence $S_{X_{j}}$, which corresponds to an equilibrium sequence $M_{i}=e=\left\{e_{0}, e_{1}, \ldots, e_{n-1}\right\}$ :

$$
S_{X_{j}}=\phi_{u}\left(M_{i}, H_{d_{k}}^{L D P C}\right)=M_{i} \times\left(H_{d_{k}}^{L D P C}\right)^{T}, \quad \text { the }
$$

number of non-zero elements of the vector $e$ does not exceed the corrective capacity of the used block $(N, M)$ code:

$$
\forall i: 0 \leq w\left(M_{i}\right) \leq t=\left\lfloor\frac{d-1}{2}\right\rfloor .
$$

The power of sets $M$ and $C$ is determined by the allowable range of weights $w\left(M_{i}\right)$, ie in the general case (for all valid values $w\left(M_{i}\right)$ ) we have:

$$
m=\sum_{i=0}^{t}(q-1)^{i} \times C_{n}^{i}, \text { where } C_{n}^{i}-\text { binomial coeffi- }
$$

cient, $C_{n}^{i}=\frac{n !}{i ! \cdot(n-1) !}$.

It is most appropriate to choose the value $w\left(M_{i}\right)$ in accordance with the required values of security of information transmission.

Then for $w\left(M_{i}\right)=$ const $=w(e)$ we have: $m=(q-1)^{w(e)} \times C_{n}^{w(e)}, \quad$ and sequence $M_{i}=\left\{e_{0}, e_{1}, \ldots, e_{n-1}\right\} \quad$ from the set $M=\left\{M_{1}, M_{2}, \ldots, M_{m}\right\}$ is formed as a result of some reflection $\psi$, implemented by redundant coding binary equilibrium codes of redundant information sequences.

The generated closed text clearly corresponds to the vector $M_{i}=\left\{e_{0}, e_{1}, \ldots, e_{n-1}\right\}$.

The public key is formed by multiplying the verification matrix of the algebraic geometric code by the masking matrix:

$$
H^{L D P C u}=X^{u} \times H^{L D P C} \times P^{u}, u \in\{1,2, \ldots, s\},
$$

where $H^{L D P C}$ - testing $N \times(N-K)$ matrix of block $(N, K)$ code with elements from $G F(q)$.

A syndromic sequence $S^{*}=\left(e_{n}\right) \times H^{L D P C^{T}}$ enters the communication channel.

On the receiving side is an authorized user who knows masking (a set of matrices $\left.\{X, P, D\}_{u}=\left\{X^{u}, P^{u}, D^{u}\right\}\right)$ and forms a code sequence as one (any) of the possible solutions of the equation:

$$
S^{*}=c_{X_{i}}^{*} \times H_{d_{k}}^{L D P C^{T}},
$$

that is, finds such a vector $c_{X_{i}}^{*}$, which decomposes into a sum: $c_{X_{i}}^{*}=c_{X_{i}}+M_{i}$, where $c_{X_{i}}$ - one (any) of the possible code words of the masked code with the test matrix $H_{d_{k}}^{L D P C^{T}}$, i.e. $c_{X_{i}} \times H_{d_{k}}^{L D P C^{T}}=0$.

Next, the authorized user using a set of matrices $\{X, P, D\}_{u}=\left\{X^{u}, P^{u}, D^{u}\right\}, \quad$ forms a vector: $\bar{c}^{*}=c_{X}^{*} \times\left(P^{u}\right)^{-1}$, that is, unmasks the code sequence 
$c_{X_{i}^{*}}^{*}$.

After substitution we get equality:

$$
\begin{aligned}
& \bar{c}^{*}=c_{X}^{*} \times\left(P^{u}\right)^{-1}=\left(c_{X_{i}}+M_{i}\right) \times\left(P^{u}\right)^{-1}= \\
& =c_{X_{i}} \times\left(P^{u}\right)^{-1}+M_{i} \times\left(P^{u}\right)^{-1} .
\end{aligned}
$$

The authorized user who created the vector has the ability to apply a fast algorithm [18]:

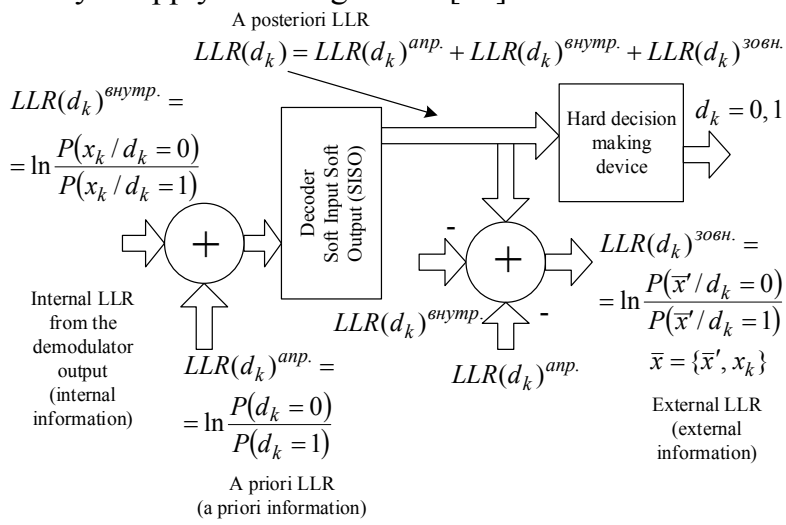

Fig. 1. Decoding scheme based on soft solutions

The following notations are entered in the diagram: $L L R$ - log-likelihood ratio (logarithm of the likelihood ratio); $d_{k}-$ code word symbol, $d_{k}=0,1, x_{k}=\left(2 d_{k}-1\right)+p_{k}, p_{k}-$ a random variable with a normal distribution with zero mean value.

From the analysis of fig. 1 it turns out that a soft solution is a logarithm of the likelihood ratio, which, in the general case, consists of several terms. The sign of the logarithm of the likelihood ratio determines the rigid decision, and the value - the reliability of this decision.

If $d_{k}, k=1,2, \ldots, K-$ statistically independent symbols that take the values 0 and 1 , and which, in the General case, correspond to the information symbols of the block code, and $\beta_{k}=\left(2 d_{k}-1\right)= \pm 1$. In this format, the result of adding characters $\beta_{k}$ modulo two will look like this:

$$
\begin{aligned}
& \beta_{1} \oplus \beta_{2}=-1, \text { if } \beta_{1}=\beta_{2} ; \\
& \beta_{1} \oplus \beta_{2}=+1, \text { if } \beta_{1} \neq \beta_{2} .
\end{aligned}
$$

Then the logarithm of the ratio of the plausibility of the sum modulo two characters $\beta_{k}-L L R\left(\beta_{1} \oplus \beta_{2} \oplus \ldots \oplus \beta_{K}\right)$ can be written as follows [18]:

$$
L L R\left(\beta_{1} \oplus \beta_{2} \ldots \oplus \beta_{k} \oplus \ldots \oplus \beta_{K}\right)=\ln \left[\frac{\sum_{k} e^{L L R\left(\beta_{k}\right)}}{1+\prod_{k} e^{L L R\left(\beta_{k}\right)}}\right] .
$$

Expression (2) can be approximated as

$\operatorname{LLR}\left(\beta_{1} \AA \beta_{2} \ldots \AA \beta_{k} \AA \ldots \AA \beta_{K}\right)$ »

$$
»-1 \times\left[\prod_{k} \operatorname{sign}\left\{L L R\left(\beta_{k}\right)\right\}\right]\left[\min _{k}\left\{\left|L L R\left(\beta_{k}\right)\right|\right\}\right],
$$

where function $\operatorname{sign}(\bullet)$ returns the sign of his argument.

Each test equation with (1) allows to express one symbol (regardless of whether it is informational or test) through the sum modulo two of all other symbols included in this test equation.

Next, the user forms a vector $\bar{c}^{*}=c_{X}^{*} \times\left(P^{u}\right)^{-1}$ and vector $M_{i}^{u}=M_{i} \times\left(P^{u}\right)^{-1}$.

To restore the information equilibrium sequence $M_{i}$ just multiply the vector again $M_{i}^{u}$ on the masking matrix:

$$
M_{i}=M_{i}^{u} \times P^{u}=M_{i} \times\left(P^{u}\right)^{-1} \times P^{u}=M_{i} .
$$

When decrypting the cryptogram after obtaining the error vector, the equilibrium coding algorithm is used to obtain information.

\section{Development of practical algorithms of Niederre-}

\section{iter CCC on LDPC-codes}

The algorithm for forming a cryptogram in a modified Niederreiter CCC will be presented as a sequence of steps:

Step 1. Entering the information to be encoded. Entering the public key $H_{d_{k}}^{L D P C}$.

Step 2. Formation of the error vector e, the weight of which does not exceed $\leq t-$ corrects the ability of the elliptical code based on the equilibrium coding algorithm.

Step 3. Formation of the codegram:

$$
S^{*}=\left(e_{n}\right) \times H_{d_{k}}^{L D P C} .
$$

The algorithm for decoding the codogram in Niederreiter CCC will be presented as a sequence of steps:

Step 1. Enter the decoded SX codogram.

Enter the private key - matrices $X, P, D$.

Step 2. Finding one of the possible solutions of the equation $S^{*}=\bar{c}^{*} \times\left(H_{d_{k}}^{L D P C}\right)^{T}$.

Step 3. Removal of the permutable matrix:

$$
\bar{c}^{*}=c_{X}^{*} \times P^{-1} \text {. }
$$

Step 4. Decoding the vector $\bar{c}^{*}$. Formation of vector $e_{x}$ ’.

Step 5. Using the LLR-decoder.

Step 6. Vector $e_{x}$ ' transformation

$$
e_{x}=e_{x}{ }^{\prime} \times P \text {. }
$$

Step 7. Transformation of the vector $e$ based on the use of the equilibrium code in the information sequence.

Using this approach allows to encrypt large amounts of data without reducing the bandwidth of communication channels in SCPS. However, changing the formation of the public key and reducing the masking matrices (practical non-use of the diagonal matrix) 
can lead to a decrease in the cryptographic strength of the Niederreiter CCC. To eliminate this shortcoming and increase the level of cryptosecurity, [3-6] proposes the use of an additional session key - an error vector, which is formed on the basis of equilibrium coding from the information block, ie. the information block is divided into two sub-blocks, the first is coded in Niederreiter $\mathrm{CCC}$ on $\mathrm{AGK}$, the second is used to form a session key. However, the decoding algorithm is an open question. Therefore, it is proposed to use the mechanisms of damage, which are proposed in [24-25]. This approach provides an additional level of cryptocurrency through the use of compression mechanisms and multi-channel cryptography.

Quantitative measure of the effectiveness of damage is the degree of destruction of the value equal to the difference between the entropies of the loss text and the source text at different segments of the length of the loss text:

$$
\begin{gathered}
d=H(F T C)-\sum_{i=1}^{S} H\left(M_{i}\right) p_{i}, \\
\sum_{i=1}^{S} p_{i}=1, s=\left[\frac{L_{0}-L_{F T C}}{L_{F T C}}\right],
\end{gathered}
$$

where $M_{i}$ - part of the source text corresponding to the $i$-th segment;

$$
p_{i}-\text { its probability; }
$$

$L_{0}-$ length $M_{i}$ equal to the length of $L_{F T C}-$ the loss text;

$s$ - number of segments.

The universal mechanism of $C_{m}$ damage can be described [1-2]:

$$
\begin{aligned}
& C F T / C H_{F T}=E_{1}\left(M, K U^{L D P C}\right), \\
& C H D / C H_{D}=E_{2}\left(M, K U^{L D P C}\right), \\
& M=E_{1,2}^{-1}\left(C F T / C H_{F T}, C H D / C H_{D}, K U^{L D P C}\right), \\
& C F T / C H_{F T}=C F T / C H_{F T}^{i}, \ldots, C F T / C H_{F T}^{m}, \\
& K U^{L D P C}=\varphi\left(K_{D}^{i}, \ldots, K_{D}^{m}, K U_{1}^{L D P C}, \ldots, K U_{m}^{L D P C},\right. \\
& C H D / C H_{D}=C H D / C H_{D}^{i}, \ldots, C H D / C H_{D}^{m} .
\end{aligned}
$$

Thus, as a result, we have two ciphertexts (loss $\left(\mathrm{CH}_{D}\right)$ and loss text $\left.(F T C)\right)$, each of which does not make sense either in the alphabet of the source text or in the alphabet of ciphertext. In fact, the ciphertext of the original message $(M)$ is presented as a set of two loss ciphertexts, each of which cannot recover the original text separately. It is not necessary to know the intermediate loss sequences to restore the original sequence. It is necessary to know only the last loss sequence (the last loss text after execution of all cycles) and all losses with rules of their drawing.
Fig. 2 shows the universal mechanism of damage (MV2 algorithm (making loss text)).

The set of transform definitions in the $M V 2$ algorithm is a set $\{0,1\}^{n}$ - considered as the power of the alphabet of a family of source texts, which is associated with some probability distribution of the letters of this alphabet, and the symbols of the source text - the value of a discrete random element [1].

Let $X-$ a random discrete element that acquires value $\quad x_{i} \in\{0,1\}^{n} \quad$ with probability $p_{i}$ and $T=(c, f) \in F_{n}^{r}-$ arbitrary fixed $M V 2$ transformation.

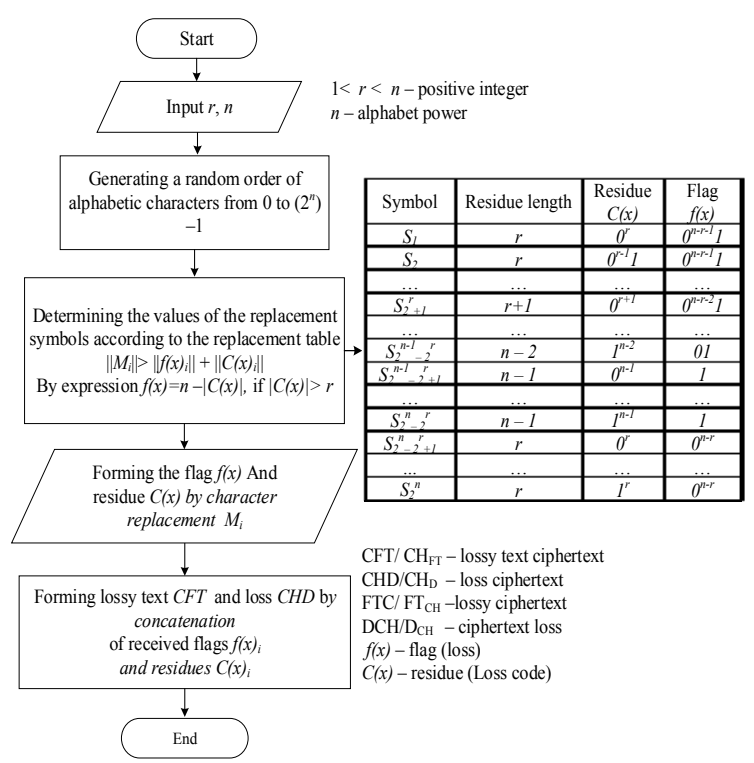

Fig. 2. Universal mechanism of damage - algorithm $M V 2$ (making loss text)

Then for any $y \in U_{r n-1}$ (some binary string from a set of strings of variable length) and for any $1 \leq i \leq|y|$ such equality is fulfilled:

$$
\#\left\{x \in\{0,1\}^{n}: c(x)=y\right\}=\#\left\{x \in\{0,1\}^{n}: c(x)=y^{(i)}\right\} .
$$

Then, regardless of the probability distribution of the random element $X$ for the entropies of the random elements $F T C / F T_{C H}$ (lossy ciphertext) and CHD (loss), the equations hold:

$$
\begin{aligned}
& H\left(F T C / F T_{C H}\right) \leq \log \left(2^{n}-2^{r}\right), \\
& H(C H D) \leq \log (n-r+1) .
\end{aligned}
$$

Thus, with a uniform distribution of inputs (flags) of the algorithm $M V 2$ formed a uniform distribution of output (balance):

$$
P\left(c_{k}=0|0 \leq k \leq| F T C / F T_{C H} \|\right)=\frac{1}{2} .
$$

In [12-13], the analysis of damage use schemes showed that the third scheme is optimal, which is presented in Fig. 3. 


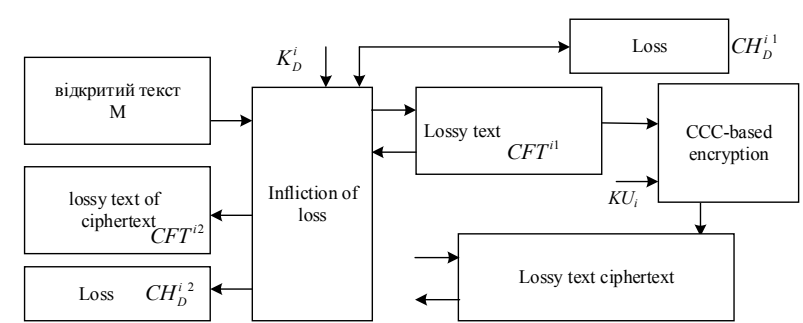

Fig. 3. Block diagram of a hybrid cryptosystem based on damage to the original text and ciphertext

The dependence of group operations of HCCC implementation on field strength is given in tabl. 1 .

Table 1

Dependence of software implementation on field strength (number of thousands of additional operations before encryption / after / amount)

\begin{tabular}{|c|c|c|c|c|}
\hline $\begin{array}{c}\text { Ap- } \\
\text { proach }\end{array}$ & $2^{5}$ & $2^{7}$ & $2^{9}$ & $2^{11}$ \\
\hline 1 & $1002 /-/ 1002$ & $3285 /-/ 3285$ & $6322 /-/ 6322$ & $11078 /-/ 8247$ \\
\hline 2 & $-/ 1501 / 1501$ & $-/ 4289 / 4289$ & $-/ 9296 / 9296$ & $-/ 15908 / 15908$ \\
\hline 3 & $992 / 1487 / 2479$ & $2952 / 4428 / 73805793 / 8690 / 1448310086 / 15130 / 25216$ \\
\hline
\end{tabular}

Tabl. 2 shows the length of the transmitted data.

Table 2

Length of transmitted data in bytes

\begin{tabular}{|c|c|c|c|c|}
\hline $\begin{array}{c}\text { Ap- } \\
\text { proach }\end{array}$ & $2^{5}$ & $2^{7}$ & $2^{9}$ & $2^{11}$ \\
\hline 1 & 500902 & 902403 & 1642357 & 2374489 \\
\hline 2 & 375298 & 667029 & 1072313 & 1652979 \\
\hline 3 & 627533 & 1044069 & 1868102 & 2716713 \\
\hline
\end{tabular}

The ratio of these values shows the bit rate of the bandwidth for each additional operation (Table 3).

Table 3

Number of bits per additional operation

\begin{tabular}{|c|c|c|c|c|}
\hline $\begin{array}{c}\text { Ap- } \\
\text { proach }\end{array}$ & $2^{5}$ & $2^{7}$ & $2^{9}$ & $2^{11}$ \\
\hline 1 & $2.5 \mathrm{E}-04$ & $4.55 \mathrm{E}-04$ & $4.812 \mathrm{E}-04$ & $4.341 \mathrm{E}-04$ \\
\hline 2 & $4.999 \mathrm{E}-04$ & $8.038 \mathrm{E}-04$ & $\mathbf{1 0 . 8 3 6 E - 0 4}$ & $\mathbf{1 2 . 0 3 E - 0 4}$ \\
\hline 3 & $4.938 \mathrm{E}-04$ & $8.836 \mathrm{E}-04$ & $9.691 \mathrm{E}-04$ & $11.602 \mathrm{E}-04$ \\
\hline
\end{tabular}

Thus, the use of the approach (Fig. 3) in inflicting damage to ciphertext from the Niederreiter MCCC on the MEC increases the bandwidth in the GF field (29). This method is the optimal approach for building a hybrid Niederreiter CCC on LDPC codes. The proposed Niederreiter CCC on LDPC codes with a cryptosystem at a loss code allows to build complex (hybrid) cryptocode condtructions (HCCC), the stability of which is determined by the stability of two cryptosystems, as well as ensure rapid cryptocurrency conversion by reducing field strength. Thus, the proposed approach provides the required level of cryptosecurity in the postquantum period, has virtually no impact on bandwidth and provides security services in the SCPS.
The mathematical model of the hybrid Niederreiter $C C C$ will be formally written down as:

- a set of open texts $M=\left\{M_{1}, M_{2}, \ldots M_{q^{k}}\right\}$, where $M_{i}=\left\{e_{0}, e_{h_{1}}, \ldots e_{h_{k}}, e_{e-1}\right\}, \quad \forall e_{e} \in G F(q), h_{e}-$ error vector symbols equal to zero, $|h|=\frac{1}{2} e$, that is $e_{i}=0, \forall e_{i} \in h$;

- a set of closed texts $S=\left\{S_{0}, S_{1}, \ldots S_{q^{r}}\right\}$, where $S_{i}=\left\{S_{X_{0}}^{*}, S_{h_{1}}^{*}, \ldots S_{h_{j}}^{*}, S_{X_{r}}^{*}\right\}, \forall S_{X_{r}} \in G F(q) ;$

- a set of direct mappings (based on the use of public key - LDPC-code check matrix: $\varphi=\left\{\varphi_{1}, \varphi_{2}, \ldots, \varphi_{r}\right\}$, where $\varphi_{i}: M \rightarrow S_{r-h_{e}}, i=1,2, \ldots, e$ - set of inverse mappings (based on the use of private key - masking matrices). $\varphi^{-1}=\left\{\varphi_{1}^{-1}, \varphi_{2}^{-1}, \ldots, \varphi_{r}^{-1}\right\}$, where $\varphi_{i}^{-1}: S_{r-h_{e}} \rightarrow M, i=1,2, \ldots, e$.

- a set of keys that parameterize direct mappings (authorized user's public key):

$$
K U_{i}=\left\{K U_{1}, K U_{2}, \ldots, K U_{r}\right\}=\left\{H_{1}, H_{2}, \ldots, H_{r}\right\},
$$

where $H_{X_{a_{i}}}^{L D P C_{i}}-$ testing $(N-K) \times N$;

- set of keys that parameterize inverse mappings (private key of the authorized user):

$$
K R=\left\{K R_{1}, K R_{2}, \ldots, K R_{r}\right\}=\left\{\begin{array}{l}
\{X, P, D\}_{1}, \\
\{X, P, D\}_{2}, \ldots,\{X, P, D\}_{r}
\end{array}\right\},
$$

$\{X, P, D\}_{i}=\left\{X^{i}, P^{i}, D^{i}\right\}$, where $X^{i}$ - masking degenerate accidentally equally likely formed by the source of the keys $k \times k$ matrix with elements of $G F(q) ; P^{i}-$ permutative randomly equally likely formed by the source of the keys $n \times n$ matrix with elements of $G F(q) ; D^{i}$ - diagonal matrix generated by the source of the keys with elements of $G F(q)$ that is $\varphi_{i}^{-1}: S_{r-h_{e}}^{*} \stackrel{K R_{i}}{\longrightarrow} M, i=1,2, \ldots, s ;$

- a set of loss texts CFT, $C F T=\left\{C F T_{1}, C F T_{2}, \ldots, C F T_{q}\right\} ;$

- set of losses

CHD, $C H D=\left\{C H D_{1}, C H D_{2}, \ldots, C H D_{q^{k}}\right\} ;$

- set of direct loss (based on the use of the key $K_{M V 2}^{i}$, and the $M V 2$ algorithm) $E=\left\{E_{K_{M V 2}}^{1}, E_{K_{M V 2}}^{2}, \ldots, \phi_{K_{M V 2}}^{S}\right\}, \quad i=1,2, \ldots, s ; \quad f(x)_{i}-$ flag (loss, $C H D$ ), $C(x)_{i}$ - residual (loss text, CFT); $f(x)=n-|C(x)|$, if $|C(x)|>r$, where $r$ - some parameter, $r \in \in_{R} Z_{q^{m}}, 0<r<n$ 
- set of MV2 mappings $F_{n}^{r}$, which sets the bijective reflection between the set of permutations $\left\{S_{1}, S_{2}, \ldots, S_{2^{n}}\right\}$ and set $\# F_{n}^{r}, \# F_{n}^{r}=\#\{(c, f)\}=2^{n}$ !;

- a set of meaningful text (based on the use of the key - $K_{M V 2}^{i}$, and algorithm MV2) $E^{-1}=\left\{E_{K_{M V 2}}^{1}{ }^{-1}, E_{K_{M V 2}}^{2}{ }^{-1}, \ldots, E_{K_{M V 2}}^{S}{ }^{-1}\right\}, \quad$ where $E_{K_{M V 2}}^{-1}:\left\|f(x)_{i}\right\|+\left\|C(x)_{i}\right\| \rightarrow M, \quad i=1,2, \ldots, s ; \quad f(x)_{i}$ - flag (loss, CHD), $C(x)_{i}$ - residual (loss text, $C F T$ ); $f(x)=n-|C(x)|$, if $|C(x)|>r$, where $r$ - some parameter, $r \in_{R} Z_{q^{m}}$.

The initial data in the description of the considered crypto-code construction are:

- equilibrium code over $G F(q)$, that is, the set of sequences length $n$;

- block $(N, K)$ - code $C$ over $G F(q)$, ie such a set of code words $C_{i} \in C$, that equality is fulfilled $C_{i} H^{T}=0$, where $H^{L D P C}-$ LDPC-code check matrix;

- masking matrix mappings defined by a set of matrices $\{X, P\}_{i}$, where $X$ - nondegenerate $k \times k$ matrix over $G F(q), P$ - permutative $n \times n$ matrix over $G F(q)$ with one non-zero element in each row and in each column of the matrix;

$\begin{array}{llll}- & r & - & \text { some }\end{array}$ $r \in_{R} Z_{q^{m}}, Z_{q^{m}}=\left\{0,1, \ldots 2^{n}-1\right\} ; n$ - some parameter $n \in_{R} Z_{q^{n}}, Z_{q^{n}}=\left\{1, \ldots 2^{n}\right\}$;

- set of mappings $M V 2-F_{n}^{r}$.

On the basis of equilibrium coding formed $\mathrm{g}$ transformation of plaintext into an error vector (plaintext $C_{j} \in C$ ) according to the entered plaintext $M_{i} \in M$ and a given key $H^{L D P C u}, u \in\{1,2, \ldots, s\}$. This is done by forming a syndrome sequence $S_{X_{j}}$, corresponding to the equilibrium sequence $M_{i}=e=\left\{e_{0}, e_{1}, \ldots, e_{n-1}\right\}$ :

$$
S_{X_{j}}=\phi_{u}\left(M_{i}, H_{d_{k}}^{L D P C}\right)=M_{i} \times\left(H_{d_{k}}^{L D P C}\right)^{T},
$$

the number of non-zero elements of the vector $e$ does not exceed the correctability of the block $(N, M)$ code used.

Formed closed text $C_{j} \in C$ clearly corresponds to the vector $M_{i}=\left\{e_{0}, e_{1}, \ldots, e_{n-1}\right\}$.

The public key is formed by multiplying the verification matrix of the algebraic geometric code by the masking matrix:

$$
H^{L D P C u}=X^{u} \times H^{L D P C} \times P^{u}, u \in\{1,2, \ldots, s\},
$$

where $H^{L D P C}$ - testing $N \times(N-K)$ matrix of block $(N, K)$ code with elements from $G F(q)$.

The $M V 2$ algorithm receives the syndrome sequence: $S^{*}=c_{X_{i}}^{*} \times H_{d_{k}}^{L D P C^{T}}$.

In $M V 2$ syndrome sequence $S^{*}$ turns into a residual and a flag:

$$
E_{K_{M V 2}}: S^{*} \rightarrow\left\|f(x)_{i}\right\|+\left\|C(x)_{i}\right\| .
$$

To the communication channel enters $\left\|f(x)_{i}\right\| m a\left\|C(x)_{i}\right\|$, the transmission can be carried out on one or two independent channels.

On the receiving side, there is an authorized user who knows the rule of loss $F_{n}^{r}$, masking (a set of matrices $\left.\{X, P\}_{u}=\left\{X^{u}, P^{u}\right\}\right)$ and initialization vector (number and location of zero characters of the error vector):

$$
E_{K_{M V 2}}^{-1}:\left\|f(x)_{i}\right\|+\left\|C(x)_{i}\right\| \rightarrow S^{*},
$$

and forms a code sequence as one (any) of the possible solutions of the equation:

$$
S^{*}=c_{X_{i}}^{*} \times H_{d_{k}}^{L D P C^{T}},
$$

that is, finds such a vector $c_{X_{i}}^{*}$, which is decomposed by the amount: $c_{X_{i}}^{*}=c_{X_{i}}+M_{i}$, where $c_{X_{i}}$ - one (any) of the possible code words of the masked code with the test matrix $H_{d_{k}}^{L D P C^{T}}$, that is $c_{X_{i}} \times H_{d_{k}}^{L D P C^{T}}=0$.

Next, the authorized user, using a set of matrices $\{X, P\}_{u}=\left\{X^{u}, P^{u}\right\}$, forms a vector: $\bar{c}^{*}=c_{X}^{*} \times\left(P^{u}\right)^{-1}$, that is, unmasks the code sequence $c^{*} X_{i}$.

After substitution, we obtain the equality:

$$
\begin{aligned}
& \bar{c}^{*}=c_{X}^{*} \times\left(P^{u}\right)^{-1}=\left(c_{X_{i}}+M_{i}\right) \times\left(P^{u}\right)^{-1}= \\
& =c_{X_{i}} \times\left(P^{u}\right)^{-1}+M_{i} \times\left(P^{u}\right)^{-1} .
\end{aligned}
$$

The authorized user who created the vector has the ability to apply a fast decoding algorithm LLR.

Next, the user forms a vector $\bar{c}^{*}=c_{X}^{*} \times\left(P^{u}\right)^{-1}$ and vector $M_{i}^{u}=M_{i} \times\left(P^{u}\right)^{-1}$.

To restore the information equilibrium sequence $M_{i}$ it is enough to multiply the vector again $M_{i}^{u}$ on the masking matrix:

$$
M_{i}=M_{i}^{u} \times P^{u}=M_{i} \times\left(P^{u}\right)^{-1} \times P^{u}=M_{i} .
$$


When decrypting the cryptogram after obtaining the error vector, the equilibrium coding algorithm is used to obtain information.

Thus, the proposed mathematical model of the hybrid Niederreiter CCC on LDPC-codes with damage allows to use additional mechanisms of multichannel cryptography, and provide the required level of stability in the post-quantum period.

\section{Conclusions}

A formal description of the mathematical models of Niederriter crypto-code construction on LDPC-codes, hybrid CCC on flawed codes, which provides the required level of crypto-strength, and security services in sociocyberphysical systems based on wireless networks without reducing bandwidth.

\section{References}

1. Grishhuk, R.V. and Danik, Ju.G. (2016), "Osnovi kiberbezpeki” [Fundamentals of cybersecurity], ZhNAEU, Zhitomir, $636 \mathrm{p}$.

2. US Department of Commerce (2016), Report on Post-Quantum Cryptography, available at: http://nvlpubs.nist.gov/ nistpubs/ir/2016/NIST.IR.8105.pdf.

3. Ankur Lohachab, Anu Lohachab and Ajay Jangra (2020), A Comprehensive Survey of Prominent Cryptographic Aspects for Securing Communication in Post-Quantum IoT Networks, Internet of Things, Vol. 9, available at: https://www.sciencedirect.com/science/article/pii/S2542660520300159.

4. Kuznecov, A., Pushkarev, A., Kavun, S. and Kalashnikov, V. (2016), "Nesimmetrichnye kriptosistemy na osnove algebraicheskogo kodirovanija: sovremennoe sostojanie, sushhestvujushhie protivorechija i perspektivy prakticheskogo ispol'zovanija na post-kvantovyj period" [Asymmetric cryptosystems based on algebraic coding: current state, existing contradic-tions and prospects for practical use in the post-quantum period], available at: https://periodicals.karazin.ua/ cscs/article/ download/7839/9850.

5. Kuznecov, A.A., Pushkarev, A.I., Svatovskij, I.I. and Shevcov, A.V. (2016), "Nesimmetrichnye kriptosistemy na algebraicheskih kodah dlja postkvantovogo perioda" [Asymmetric cryptosystems on algebraic codes for the post-quantum period], Radyotekhnyka, Vol. 186, pp. 70-90, available at: https://openarchive.nure.ua/handle/document/4642.

6. Kuznecov, O., Pushkar'ov, A., Shevcov, O. and Kuznecova, T. (2016), "Nesimetrichne kriptografichne peretvorennja z vikoristannjam algebraichnih blokovih kodiv" [Asymmetric cryptographic transformation using algebraic block codes], Information protection, Vol. 18, No. 4, pp. 269-275. https://doi.org/10.18372/2410-7840.18.11088.

7. Positive Technologies (2017), "Ugrozy bezopasnosti jadra paketnoj seti 4G”' [4G packet kernel security threats], available at: https://www.ptsecurity.com/ru-ru/research/analytics/epc-2017/.

8. Positive Technologies (2018), “Ujazvimosti protokola Diameter v setjah 4G” [Diameter vulnerabilities in 4G networks], available at: https://www.ptsecurity.com/ru-ru/research/analytics/diameter-2018/.

9. Guide to LTE Security, available at: csrc.nist.gov/publications/drafts/80187/sp800_187_draft.pdf.

10. Niederreiter, H. (1986), Knapsack-Type Cryptosystems and Algebraic Coding Theory, Probl. Control and Inform. Theory, Vol. 15, pp. 19-34.

11. Yevseiev, S., Tsyhanenko, O., Ivanchenko, S., Aleksiyev, V., Verheles, D., Volkov, S., Korolev, R., Kots, H., Milov, O. and Shmatko, O. (2018), Practical implementation of the Niederreiter modified crypto-code system on truncated elliptic codes, Eastern-European Journal of Enterprise Technologies, No. 6/4 (96), pp. 24-31.

12. Yevseiev, S., Tsyhanenko, O., Gavrilova, A., Guzhva, V., Milov, O., Moskalenko, V., Opirskyy, I., Roma, O., Tomashevsky, B. and Shmatko, O. (2019), Development of Niederreiter hybrid crypto-code structure on flawed codes, EasternEuropean Journal of Enterprise Technologies, No. 1/9 (97), pp. 27-38.

13. Yevseiev, S., Ponomarenko, V., Laptiev, O. and Milov, O. (2021), Synergy of building cybersecurity systems: monograph, PC TECHNOLOGY CENTER, Kharkiv, 188 p.

14. Krasnov, R.P. (2018), "Sistema atmosfernoj opticheskoj svjazi OFDM-TIPA na baze koda LDPC s peremezheniem v turbulentnom kanale" [Atmospheric optical communication system OFDM-TYPE based on LDPC code with interleaving in a turbulent channel], Voronezh State Technical University Bulletin, Vol. 14, No. 4, available at: $\mathrm{https} / /$ cyberleninka.ru/article/n/sistema-atmosfernoy-opticheskoy-svyazi-ofdm-tipa-na-baze-koda-ldpc-s-peremezheniem-vturbulentnom-kanale.

15. HAL Science Ouverte (2015), QC-MDPC-McEliece: A public-key code-based encryption scheme based on quasi-cyclic moderate density parity check codes, available at: https://hal.archives-ouvertes.fr/hal-01095935.

16. Misoczki, Rafael, Tillich, Jean-Pierre, Sendrier, Nicolas and Barreto, Paulo S.L.M. (2013), MDPC-McEliece: New McEliece Variants from Moderate Density Parity-Check Codes, available at: https://eprint.iacr.org/2012/409.pdf.

17. Bashkirov, A.V., Sitnikov, A.V. and Horoshajlova, M.V. (2015), "Optimizacija apparatnoj arhitektury LDPCdekodera,primenjaemogo $v$ standarte radiosvjazi IEEE 802.11n" [Optimization of the hardware architecture of the LDPC decoder used in the radio standard IEEE $802.11 \mathrm{n}]$, available at: https://cyberleninka.ru/article/n/optimizatsiya-apparatnoyarhitektury-ldpc-dekodera-primenyaemogo-v-standarte-radiosvyazi-ieee-802-11n.

18. Zhuchenko, O.S. (2008), “Znahodzhennja m'jakih rishen' dlja simvoliv zavadostijkogo blokovogo kodu na osnovi perevirochnih rivnjan"' [Finding soft solutions for noise-tolerant block code symbols based on test equations], Telekomunikacijni sistemi ta merezhi na zaliznichnomu transporti, UkrDAZT, Vol. 98, pp. 61-64.

19. Sviridova, I.V. and Horoshajlova, M.V. (2019), "Ispol'zovanie nejronnyh setej dlja optimizacii dekodirovanija LDPCkodov dlja 5G besprovodnoj seti” [Using neural networks to optimize decoding of LDPC codes for a 5G wireless network], 
Voronezh State Technical University Bulletin, URL: https://cyberleninka.ru/article/n/ispolzovanie-neyronnyh-setey-dlyaoptimizatsii-dekodirovaniya-ldpc-kodov-dlya-5g-besprovodnoy-seti.

20. Akulinin, S.A. and Sviridova, I.V. (2015), "Vybor parametrov LDPC-kodov dlja kanalov s additivnym belym gaussovskim shumom" [Selection of LDPC Codes Parameters for Channels with Additive White Gaussian Noise], available at: $\mathrm{https://cyberleninka.ru/article/n/vybor-parametrov-ldpc-kodov-dlya-kanalov-s-additivnym-belym-gaussovskim-shumom.}$

21. Computer security Resource Center (2020), PQC Standardization Process: Third Round Candidate Announcement. available at: https://csrc.nist.gov/News/2020/pqc-third-round-candidate-announcement.

22. Sidel'nikov, V. M. (2002), "Kriptografija i teorija kodirovanija" [Cryptography and coding theory], Materialy konferencii "Moskovskij universitet i razvitie kriptografii v Rossii”, MGU, Moscow, pp. 1-22.

23. Technical Specification (2018), 3GPP TS 38.212 V15.3.0. 3rd Generation Partnership Project; Technical Specification Group Radio Access Network; NR; Multiplexing and channel coding (Release 15).

24. Mishhenko, V.A. and Vilanskij, Ju.V. (2007), "Ushherbnye teksty i mnogokanal'naja kriptografija" [Damaged texts and multichannel cryptography], Jenciklopediks, Minsk, $292 \mathrm{p}$.

25. Mishhenko, V.A., Vilanskij, Ju.V. and Lepin, V.V. (2006), “Kriptograficheskij algoritm MV 2" [Cryptographic algorithm $M V$ 2], Minsk, $177 \mathrm{p}$.

\section{Список літератури}

1. Грищук Р. В., Даник Ю. Г. Основи кібербезпеки. Житомир : ЖНАЕУ, 2016. 636 с.

2. US Department of Commerce. Report on Post-Quantum Cryptography. URL: http://nvlpubs.nist.gov/ nistpubs/ir/2016/NIST.IR.8105.pdf.

3. Ankur Lohachab, Anu Lohachab, Ajay Jangra. A Comprehensive Survey of Prominent Cryptographic Aspects for Securing Communication in Post-Quantum IoT Networks. Internet of Things. Vol. 9. URL: https://www.sciencedirect.com/ science/article/pii/S2542660520300159.

4. Кузнецов А., Пушкарев А., Кавун С., Калашников В. Несимметричные криптосистемы на основе алгебраического кодирования: современное состояние, существующие противоречия и перспективы практического использования на пост-квантовый период. 2016. URL: https://periodicals.karazin.ua/cscs/article/download/7839/9850.

5. Кузнецов А. А., Пушкарев А. И., Сватовский И. И., Шевцов А. В. Несимметричные криптосистемы на алгебраических кодах для постквантового периода. Радиотехника : Всеукр. межвед. науч.-техн. сб. 2016. Вып. 186. С. 70-90. URL: https://openarchive.nure.ua/handle/document/4642.

6. Кузнецов О., Пушкарьов А., Шевцов О., Кузнецова Т. (2016) Несиметричне криптографічне перетворення 3 використанням алгебраїчних блокових кодів. Захист інформації. 2016. Том 18. № 4. С. 269-275. https://doi.org/10.18372/24107840.18.11088

7. Positive Technologies. Угрозы безопасности ядра пакетной сети 4G : веб-сайт. URL: https://www.ptsecurity.com/ ru-ru/research/analytics/epc-2017/.

8. Positive Technologies. Уязвимости протокола Diameter в сетях $4 G$ : веб-сайт. URL: https://www.ptsecurity.com/ru$\mathrm{ru} /$ research/analytics/diameter-2018/.

9. Guide to LTE Security: web site. URL: csrc.nist.gov/publications/drafts/80187/sp800_187_draft.pdf.

10. Niederreiter H. Knapsack-Type Cryptosystems and Algebraic Coding Theory. Probl. Control and Inform. Theory. 1986. Vol. 15. P. 19-34.

11. Yevseiev S., Tsyhanenko O., Ivanchenko S., Aleksiyev V., Verheles D., Volkov S., Korolev R., Kots H., Milov O., Shmatko O. Practical implementation of the Niederreiter modified crypto-code system on truncated elliptic codes. EasternEuropean Journal of Enterprise Technologies. 2018. No. 6/4 (96). P. 24-31.

12. Yevseiev S., Tsyhanenko O., Gavrilova A., Guzhva V., Milov O., Moskalenko V., Opirskyy I., Roma O., Tomashevsky B., Shmatko O. Development of Niederreiter hybrid crypto-code structure on flawed codes. Eastern-European Journal of Enterprise Technologies. 2019. No. 1/9 (97). P. 27-38.

13. Yevseiev S., Ponomarenko V., Laptiev O., Milov O. Synergy of building cybersecurity systems: monograph. Kharkiv : PC TECHNOLOGY CENTER, 2021. $188 \mathrm{p}$.

14. Краснов Р. П. Система атмосферной оптической связи OFDM-TИПА на базе кода LDPC с перемежением в турбулентном канале. Вестник Воронежского государственного технического университета. 2018. Tом 14. № 4. URL: https://cyberleninka.ru/article/n/sistema-atmosfernoy-opticheskoy-svyazi-ofdm-tipa-na-baze-koda-ldpc-s-peremezheniem-vturbulentnom-kanale

15. HAL Science Ouverte. QC-MDPC-McEliece: A public-key code-based encryption scheme based on quasi-cyclic moderate density parity check codes: web site. URL: https://hal.archives-ouvertes.fr/hal-01095935.

16. Misoczki Rafael, Tillich Jean-Pierre, Sendrier Nicolas, Barreto Paulo S.L.M. MDPC-McEliece: New McEliece Variants from Moderate Density Parity-Check Codes. URL: https://eprint.iacr.org/2012/409.pdf.

17. Башкиров А. В., Ситников А. В., Хорошайлова М. В. Оптимизачия аппаратной архитектуры LDPCдекодера,применяемого в стандарте радиосвязи IEEE 802.11n. 2015. URL: https://cyberleninka.ru/article/n/optimizatsiyaapparatnoy-arhitektury-ldpc-dekodera-primenyaemogo-v-standarte-radiosvyazi-ieee-802-11n.

18. Жученко О. С. Знаходження м’яких рішень для символів завадостійкого блокового коду на основі перевірочних рівнянь. Телекомунікаційні системи та мережі на залізничному транспорті: збірник наукових праць. Харків : УкрДАЗТ, 2008. Вип. 98. С. 61-64. 
19. Свиридова И. В., Хорошайлова М. В. Использование нейронных сетей для оптимизации декодирования LDPCкодов для 5G беспроводной сети. Вестник Воронежского государственного технического университета. 2019. URL: https://cyberleninka.ru/article/n/ispolzovanie-neyronnyh-setey-dlya-optimizatsii-dekodirovaniya-ldpc-kodov-dlya-5gbesprovodnoy-seti.

20. Акулинин С. А., Свиридова И. В. Выбор параметров LDPC-кодов для каналов с аддитивным белым гауссовским шумом. URL: https://cyberleninka.ru/article/n/vybor-parametrov-ldpc-kodov-dlya-kanalov-s-additivnym-belymgaussovskim-shumom.

21. Computer security Resource Center. PQC Standardization Process: Third Round Candidate Announcement. 2020. web site. URL: https://csrc.nist.gov/News/2020/pqc-third-round-candidate-announcement.

22. Сидельников В. М. Криптография и теория кодирования. Материаль конференции “Московский университет и развитие криптографии в России. Москва : МГУ, 2002. С. 1-22.

23. Technical Specification. 3GPP TS 38.212 V15.3.0. 3rd Generation Partnership Project; Technical Specification Group Radio Access Network; NR; Multiplexing and channel coding (Release 15).

24. Мищенко В. А., Виланский Ю. В. Ущербные тексты и многоканальная криптография. Минск : Энциклопедикс, 2007. 292 c.

25. Мищенко В. А., Виланский Ю. В., Лепин В. В. Криптографический алгоритм MV 2. Минск, 2006. 177 с.

\section{Відомості про авторів:}

\section{Погасій Сергій Сергійович}

кандидат економічних наук доцент доцент кафедри Харківського національного економічного університету ім. С. Кузнеця, Харків, Україна https://orcid.org/0000-0002-4540-3693

\section{Мілевський Станіслав Валерійович} кандидат економічних наук доцент Харківського національного економічного університету ім. С. Кузнеця, Харків, Україна https://orcid.org/0000-0001-5087-7036

\section{Жученко Олександр Сергійович кандидат технічних наук доцент Українського державного університету залізничного транспорту, \\ Харків, Україна https://orcid.org/0000-0003-3275-810X}

\section{Томашевський Богдан Паїсійович}

кандидат технічних наук старший науковий співробітник доцент кафедри Тернопільського національного технічного університету ім. І. Пулюя, Тернопіль, Україна https://orcid.org/0000-0002-1934-4773

\section{Рагімова Ірада Рагім кизи}

кандидат технічних наук доцент

Азербайджанського Технічного Університету,

Баку, Азербайджанська Республіка

https://orcid.org/0000-0003-3278-3225

\section{Сергісв Сергій Віталійович}

Науково-дослідний центр ракетних військ і артилерії, Суми, Україна

https://orcid.org/0000-0001-7062-5469

\section{Information about the authors:}

\section{Serhii Pohasii}

$\mathrm{PhD}$ in Economics Associate Professor

Associate Professor of Simon Kuznets

Kharkiv National University of Economics,

Kharkiv, Ukraine

https://orcid.org/0000-0002-4540-3693

\section{Stanislav Milevskyi}

$\mathrm{PhD}$ in Economics Associate Professor

of Simon Kuznets

Kharkiv National University of Economics, Kharkiv, Ukraine

https://orcid.org/0000-0001-5087-7036

\section{Oleksandr Zhuchenko}

$\mathrm{PhD}$ in Engineering Associate Professor

of Ukrainian State University

of Railway Transport,

Kharkiv, Ukraine

https://orcid.org/0000-0003-3275-810X

\section{Bogdan Tomashevsky}

$\mathrm{PhD}$ in Engineering Senior Researcher

Associate Professor

of Ternopil Ivan Puluj National Technical University,

Ternopil, Ukraine

https://orcid.org/0000-0002-1934-4773

\section{Irada Rahim qizi Rahimova}

$\mathrm{PhD}$ in Engineering Associate Professor

of Azerbaijan Technical University,

Baku, Azerbaijan

https://orcid.org/0000-0003-3278-3225

\section{Serhii Serhiiev}

Scientific- research center of missile troops and artillery,

Sumy, Ukraine

https://orcid.org/0000-0001-7062-5469 


\section{РОЗРОБКА МОДЕЛЕЙ КРИПТО-КОДОВОЇ КОНСТРУКЦІЇ НІДЕРРАЙТЕРА НА LDРС-КОДАХ}

\section{С.С. Погасій, С.В. Мілевський, О.С. Жученко, Б.П. Томашевський, І.Р. Рагимова, С.В. Сергієв}

Розвиток мобільних технологій та обчислювальних ресурсів розширив спектр ичифрових послуг та практично випередив розвиток комп'ютерних технологій. Такий підхід забезпечує використання мобільних та бездротових мереж практично у всіх напрямках смарттехнологій, забезпечує подальший синтез кіберпростору та мобільного Інтернету. Проте відсутність протоколів послуг безпеки: конфіденційності та цілісності спочатку при їх формуванні у структурі технологій LTE забезпечує кіберзловмисникам можливість використання каналів мобільного Інтернету для реалізаиіі цілььових (АРТ) атак. Розвиток та поява повномасштабного квантового комп'ютера з алгоритмами Шора та Гровера можуть призвести до різкого зниження рівня стійкості криптосистем на основі симетричної та несиметричної криптографії (включаючи та криптографію на еліптичних кривих). Крім цього, сучасні кіберзагрози мають ознаки синергізму та гібридності, а їх комплексування з методами сочіальної інженерії практично не дозволяють забезпечити необхідний рівень превентивних заходів (захист). У статті пропонуються постквантові криптосистеми на основі криптокодової конструкиії Нідеррайтера на кодах з малою щільністю перевірок на парність (LDPC-кодах). Такий підхід дозволяє “легко" інтегруватися в бездротові мережі на основі стандартів IEEE 802.16 та IEEE 802.15.4, а також мобільних технологій LTE. При иьому забезпечити необхідний рівень стійкості до сучасних загроз.

Ключові слова: модифікована крипто-кодова конструкиія Нідеррайтера, постквантовий період, коди з малою щзільністю перевірок на парність.

\section{РАЗРАБОТКА МОДЕЛЕЙ КРИПТО-КОДОВОЙ КОНСТРУКЦИИ НИДЕРРАЙТЕРА НА LDРС-КОДАХ}

\section{С.С. Погасий, С.В. Милевский, А.С. Жученко, Б.П. Томашевский, И.Р. Рагимова, С.В. Сергеев}

Развитие мобильных технологий и вычислительных ресурсов расширило спектр цифровых услуг и практически опередило развитие компьютерных технологий. Это определяет использование мобильных и беспроводных сетей практически по всем направлениям смарттехнологий, обеспечивает дальнейтий синтез киберпространства и мобильного Интернета. Однако отсутствие протоколов услуг безопасности: конфиденциальности и иелостности при их формировании в структуре технологий LTE обеспечивает киберзлоумышленникам возможность использования каналов мобильного Интернета для реализации целевых атак. Развитие и появление полномасштабного квантового компьютера с алгоритмами Шора и Гровера могут привести к резкому снижению уровня устойчивости криптосистем на основе симметричной и несимметричной криптографии (включая криптографию на эллиптических кривых). Кроме этого, современные киберугрозы имеют признаки синергизма и гибридности, а их комплексирование с методами социальной инженерии практически не позволяют обеспечить необходимый уровень превентивных мер защиты. В статье предложены постквантовые криптосистемы на основе крипто-кодовой конструкиии Нидеррайтера на кодах с малой плотностью проверок на четность (LDPC-кодах). Такой подход позволяет “легко” интегрироваться в беспроводные сети на основе стандартов IEEE 802.16 и IEEE 802.15.4, а также мобильных технологий LTE. При этом обеспечить необходимый уровень устойчивости к современным угрозам.

Ключевые слова: модифииированная крипто кодовая конструкиия Нидеррайтера, постквантовый период, коды с малой плотностью проверок на четность. 